\title{
Core Conventions of the International Labour Organisation (ILO): Implications for Nigerian Labour Laws
}

\author{
Samuel Emeka Mbah (Corresponding author) \\ Department of Industrial Relations and Personnel Management, University of Lagos \\ Akoka, Yaba, Lagos, Nigeria. \\ Tel: +233-5461-54377_E-mail: mbasam2011@yahoo.com \\ C. O. Ikemefuna \\ Department of Industrial Relations and Personnel Management, University of Lagos \\ Akoka, Yaba, Lagos, Nigeria. \\ Tel: +233-080-2304-0845 E-mail: cyikem_unilag@yahoo.co.uk
}

Received: December 15, $2010 \quad$ Accepted: February 17, 2011 doi:10.5430/ijba.v2n2p129

\begin{abstract}
This paper examines core conventions of the International Labour Organization with possible effects on Nigerian Labour Law. The paper highlights the reasons why the ILO was established, one of which the author states as dealing with social welfare policies on employment of children, among others. The author adopts a theoretical approach, the structural functionalist theory by Talcott Parson to explain the dynamics of the international labour organization. The paper further identifies some of the ILO core Conventions to include, forced labour convention No.29 of 1930, Freedom of Association and protection of the right to organize convention No. 87 of 1948, Right to organize a Collective Bargaining Convention No. 98 of 1949, Occupational Safety and Health No. 155 of 1981 and so on. The paper associates the origin of the Nigerian Labour Law with some of the ILO ratified Legislation which took the form of recommendations. ILO expects member nations that have ratified its conventions to be bound by them. But in international law, it is not an easy thing. In a country like Nigeria with a dualist system any international treaty or law or legislation must be domesticated by the National Assembly before it can be enforced in Nigeria. Backing this up the paper cites section 12 of the constitution of the Federal Republic of Nigeria, 1999, which is a ground norm. Therefore, an ILO Convention that has not been passed into Law in Nigeria cannot be legally enforced. The paper maintains that this explains why some treaties, legislation or laws that have not been domesticated have failed to be enforced in Nigeria. The author finally concludes that in spite of all these that ILO is a dynamic organization that plays diversified roles in international labour matters. That it's operation at global level should be supported and encouraged to better the life of numerous workers across the member nations.
\end{abstract}

Keywords: Core conventions, ILO, Labour laws and ground norm

\section{Introduction}

The International Labour Organization (ILO) was established in 1919 with 42 members as part of the new world order as expressly declared in the treaty of Versailles. The ILO according to David and Patricia (1993) is one of the oldest international organizations presently in operations and is commonly understood to be one of the most successful as well. The International Labour Organization (ILO) is the tripartite United Nations agency that brings together, government, employers and workers of its member states in common action to promote decent work throughout the world. Taurus, (2006), confirmed that ILO is indeed concerned with global labour matters. Apart from organizing training courses across border of the member nations, the core elements of the ILO's broad mandate include social welfare policies on:

- $\quad$ issues as diverse as working conditions,

- $\quad$ the employment of children,

- freedom of association,

- $\quad$ forced labour, 
- organized labour,

- collective bargaining rights,

- expansion of welfare programs,

- to homogenize labour practices across competing economies,

- blunt social unrest,

- $\quad$ promote social justice, etc. (Aturu, 2006).

Prior to 1919, international coordination of welfare policy occurred through bilateral treaties seeking to stem labour migration between bordering countries by equivalent working conditions for foreign nationals in each country.

The states are regarded as forming a partnership aimed at the construction of arrangements that are at once economically dynamic and socially equitable as well as provide an enabling environment for the active participation of member nations. Other major concern of ILO as identified by Onasanya (2005), is to lay down standards that are to be followed by members. The standards so set can be either by the ILO conventions or by the ILO recommendations adopted at its central conference. The ILO convention is designed to be ratified by member states.

In Onasanya's explanation, when a state ratified a Convention, it undertakes to make the standards set by the Convention applicable within its territory and amends its laws to reflect the standards, and where the country has no law relating to the standards, it has to enact one in line with the ILO standards as provided in the article of the convention. Following this explanation therefore, it implies that every ratification of the ILO conventions create a binding force on member nations except until the nation ratifies it, the state cannot be bound by it. In respect of recommendation it is designed to set standards which would serve as a guide for action when a country is formulating its social policy especially the aspect relating to labour. It is however expected that the recommendation be formally communicated to the member nations and to the notice of the authority within whose competence the matter lies or the enactment of the required legislation or action.

Unlike the ILO convention, an ILO recommendation does not require the ratification of member states, the acceptance of an ILO recommendation also does not create a binding force on any member state that accepts it (Onasanya, 2005). Nigeria being a member state of the ILO has ratified many of its conventions and accepted its recommendations. Adewumi (2010) pointed out that national and international instruments have been devised to protect workers' rights which have been codified in national laws and international labour conventions and recommendations of the International Labour Organization (ILO) in addition to constitutional provisions which also confer on them certain rights as citizens. Adewumi further stated that unfortunately these instructions are observed in the breach because employers of labour value their profits more than the workers. Such Conventions as freedom of association and protection of the right to organize convention N0 87 of 1948, forced labour convention, No 29 of 1930, occupational safety and health convention N0155 of 1981, etc. These conventions and recommendations reflect and have relevance in the ways choice of actions and decisions are taken. Convention 87, for example protects the right of workers and employers organizations to draw up their constitutions and rules to elect their representatives in full freedom, to organize their administration and activities and to formulate their programmes (Article 2). Public authorities are enjoined to refrain from any interference which could restrict this right or impede its exercise (article 3(2). Workers and employers organization cannot be dissolved or suspended by administrative authority (article 4). It becomes very clear that the dissolution by law of NUPENG and PENGASSAN executive committees by the military administration in 1994 was clearly in contravention of Nigeria's international obligations.

In spite of these international organizations, it is on record that Nigeria has failed to ratify many conventions and recommendations of the ILO, having ratified only 28 out of 170 as of 1990 (Adewumi, 2002). This conservative attitude singularly demonstrated the Nigeria's support and fellowship with Britain and other east European countries when they found reasons not to ratify various conventions and recommendations of the International Labour Organization and resolutions of the United Nation Organization (Otobo, 1988). This is because conventions and recommendations can be made easily but it is yet another problem to have them implemented by member countries hence they are reduced to mere whistle - blowing. The main rationale of this paper therefore is to examine Core conventions of the International Labour Organization and how these Conventions influence labour laws in Nigeria. For this reason this paper is structured into the following sub-headings:

- $\quad$ theoretical underpinnings,

- $\quad$ ILO millennium objectives,

- $\quad$ the organizational structure of ILO, 
- $\quad$ core ILO Conventions,

- $\quad$ implications for labour laws in Nigeria and

- conclusion.

\section{Theoretical Underpinnings}

The structural functionalist perspective by Parson (1951), tacitly explains the dynamics of the international labour organization. The structural functionalist approach which is a sociological strand sees the organization as a whole body of system that consists of structural units or components and each performing certain essential functions which in sociological term is referred to as 'functional prerequisites'. It is the functioning of these prerequisites that result to pattern maintenance of the organization which in turn enables it to achieve its set objectives. The International Labour Organization (ILO) is a whole body system that is dynamic, with institutionalized functional structures or units which operate in a changing environment. These structural units or component parts are charged with various responsibilities. These component parts include, the international labour conference, the Governing body and the international labour office.

These three organs are usually formed from the representatives of government, employers and labour. This is the reason why the three organs are popularly referred in ILO literature as "social partners" which is formed on tripartite basis. Lending support to this Okougbo (2004) maintained that tripartism within member states promotes social dialogue which involves trade unions, employers and the governments, Okougbo further stated that they debate and assist in the formulation and implementation where appropriate in national policy on social economic affairs and a host of other issues, and representatives speak during debates and vote independently.

Without these structures in place, the ILO defined objectives may be difficult to realize. Each of the component structure has its functional prerequisite which when performed enables continuity of the entire system - ILO. The ILO's social welfare policies $n$ maintenance function of the sub-units (Aberle \& Cohen, 1950).

Every part of the organization can be understood with reference to the functions they perform in meeting the adaptation, goal attainment, integration and pattern maintenance functions of these sub-systems. Emery (1980) in explaining the tenets of the socio-technical system, maintained that the independent functioning of any organ or group is usually predicated on socio- technical systems approach which suggests that the best results are obtained if grouping is such that functions are primarily related to each other by the task performance and task interdependence. This is clearly exemplified in ILO organizational structure that illustrates social and responsibility flow with the activities of the organs specified and interdependent. This arrangement greatly sustains the long term existence of ILO.

The logical advantages that emanate from structural functions of each unit include; consensus, or maintenance of equilibrium amongst component units, shared values, industrial peace and harmony amongst member nations while its major disadvantage is the conservative nature or approach in the way issues of international concern are handled. It is important at this point however to turn to the organisational structure of international labour organization and the roles they play in enacting, ratifying, recommending and or implementing labour standards.

\section{ILO Millennium Objectives}

Okougbo(2004) noted that the ILO adopted some strategic objectives for the new millennium at its 1999 International labour conference. They include, to promote and realize fundamental principles and rights at work, to create greater opportunities for women and men, to secure decent employment and income, to enhance the coverage and effectiveness of social protection for all and to strengthen tripartism and social dialogue. These millennium objectives are in line with the Declaration of Philadelphia which the ILO constitution affirmed that Universal and lasting peace can be established only if it is based on social justice. So in 1944 the Philadelphia ILO conference meeting adopted the declaration which embodies the following principles, labour is not a commodity, freedom of expression and of association are essential to sustained progress, poverty anywhere constitutes a danger to prosperity everywhere, and all human beings, irrespective of race, creed or sex, have the right to pursue both their material well being and their spiritual development in conditions of freedom and dignity of economic security and equal opportunity.

\section{The Organisational Structure of ILO}

The International Labour Organization (ILO) consists of the following structures, the representatives of: government of member countries, employers and labour.

The salient point about this structure is the subsequent formation of the three organs from these representatives namely the International Labour Conference, the Governing Body and the International Labour Office. Each of these organs performs its functions as required by the system. International Labour Conference meets annually in June at the 
headquarters in Geneva, member states are entitled to send four (4) delegates who are to be representatives of government precisely cabinet minister in charge of labour, permanent secretary or a director in the ministry of labour, employers and Labour to the conference made up of two from government and one each from employers and the workers. At the conference, labour and social problems are discussed before being reduced into a convention and subsequent recommendation. Both employer and worker delegates can have the freedom of speech but may vote independently even against their government for ideological reasons.

The Governing body is also on the basis of tripartism. It is made up of 28 government members, 14 employer members, and 14 worker members, a total of 56 persons that constitute the governing body (Bamidele, 2006). The body acts like the board or Executive council of the ILO. It meets three times yearly and sets agenda for the organization, elects the director general and carries out over sight functions. It is the supreme body and can be regarded as performing the executive functions of the organization. The next structure is the International Labour Office located in Geneva. This is the secretariat which is the administrative head of the ILO. It deals with the day- to- day running of the organization. Its management is decentralized in regional, area and branch offices. Meetings can be held periodically at the regions.

The Director General is the head of the secretariat. The administration is however decentralized with regional, Area and Branch Offices across the world. This division made possible effective communication of information and effective management of labour issues across borders. Its branch office in Nigeria is located in Lagos State.

At this point it is proper to examine some of the core ILO Conventions.

\section{Core ILO conventions}

Here we shall consider some major ILO conventions with a view to highlighting their salient provisions. They include Forced Labour Convention No. 29 of 1930

The convention was adopted on 28th of June, 1930. it imposes an obligation on countries that have ratified the convention to "suppress the use of force or compulsory labour in all its form" (Article 1).Shading more light to this the issue of child abuse is growing to an alarming proportion and the most agonizing one now being that of ritual killing and prostitution. It is therefore important there is a need for more security in this country to protect children by making laws that will protect the life of the child. It is the responsibility of government to promulgated such laws that will arresting child abuse.

Freedom of Association \& Protection of the Right to Organize Convention No. 87 of 1948 This convention is fundamental to the exercise of collective labour rights by trade unions and unionists. It was adopted on the 9th of July 1948. Nigeria is a signatory to the convention. It provides that workers and employers have the right to establish or join organizations of their own choice without previous authorization (Article 2). This is similar to the right guaranteed by section 40 of the constitution on the right to associate freely and form trade union

Right to Organize a Collective Bargaining Convention No 98 of 1949 The convention seeks to protect the rights of stakeholders in industrial relations to bargain voluntarily. It has also been ratified by Nigeria. It prohibits anti-union discrimination against workers Article 1 (1).

Occupational Safety and Health Convention No. 155 of 1981 The convention was adopted on the 22nd of June, 1981. it applies to all employed persons including public employees and covers all places where workers need to be or to go by reason of their work which are under the direct or indirect control of the employers, (Article $2 \& 3$ ). Below are highlights of major post independence legislation based on ILO ratified conventions 1960-1993:

- basic Human Rights Legislation

- $\quad$ trade Unions International Affiliation Decree 35 of 1989, Laws of 1989.

- $\quad$ trade Unions International Affiliation Act. Cap 438, Laws of Federation of Nigeria 1990.

Trade Union Legislations in Nigeria 1993-1996.

- employment policy and promotion legislation

- labour Administration Legislations

- conditions of Work Legislation

- employment of women legislation

- $\quad$ employment of children and young persons

- migrant workers legislation 
- $\quad$ indigenous workers legislation

- $\quad$ maritime conventions: safety, health and welfare of maritime workers legislation.

- $\quad$ occupational safety and health legislation

- $\quad$ social security legislation

- $\quad$ colonial correspondence dated 21st Nov. 1946 to the government of Nigeria on minimum standard of social policy in independent territories Recommendation of 1944-1945.

- $\quad$ legislations enacted as a result of wage fixing machinery convention. (NAI/Comc. 11) 1138, Vol 2, International Labour Conference PP.101-110).

It is important to remark that there are so many conventions held before and after the independence, and one thing that is more important to note is that most of the labour laws in Nigeria are like the toothless bull dog having some teeth but cannot bite; they are ineffective and in operative, so need to be reviewed. The next section of this paper deals with the possible effects of ILO Conventions on Nigerian Labour Law.

\section{Implications for Labour Laws in Nigeria}

Nigeria at independence inherited some English common laws that regulate the practice of industrial relations in Nigeria. Other laws can be found in statutes which were enacted at various times for Nigeria either by the colonial parliament, the pre-military parliament, the military decrees, the post-military, or the civilian National Assembly (Esan, 1987).ILO labour standards are part of such statutory laws that are made for Nigeria. It is very obvious that ILO Conventions produce labour standards which had influence on the Nigerian Labour Law. These effects are most greatly in the following aspects:

- $\quad$ In the constitution of the Federal Republic Of Nigeria, the sections that deal with labour matters are mostly lifted from the ILO Conventions and inculcated into the constitution.

- $\quad$ The major effects are on social welfare services that deal specifically with labour issues including trade unions industrial relations, safety and welfare of Labour, industrial dispute, prescribing a national minimum wage for the federation or any part thereof, and industrial arbitrations. All these are produced first as labour standards before they now became law that can be enforced.

Till date, the labour standards play a very vital role in regulating contracts of employment particularly in those areas where our law does not cover. Some of these labour standards in Nigerian labour Law are replication of ILO legislation.

In support of this claim Esan quoted in Otobo (1987) expressed that: The core area of the ILO concern is the social welfare services that deal specifically with the provision of

- $\quad$ the minimum terms and conditions of employment of workers as contained in the Labour Act 1974,

- $\quad$ the provision for the formation, registration, recognition and operation of trade unions, including central labour organization as contained in the Trade Union Act 1973,

- $\quad$ the provision for safety and protection against industrial injuries as contained in the factories Act mining regulations,

- $\quad$ the provision for the payment of compensation to persons who get incapacitated as a result of injury suffered at work or to the dependants of persons who die as a result of accidents happening in the course of their employment as contained in the workmen's compensations Act and the relevant rules,

- the provisions for collective bargaining and the settlement of trade disputes as contained in the trade Disputes Act, 1976 ,

- $\quad$ the provisions for the establishment of wages Board for the protections of workers in places where wages are unreasonably low or where no machinery exists for the effective regulation of wages or other conditions of employment as contained in the wages boards and industrial council Act, 1973, among others.

The ILO expects members that have ratified its conventions to be bound by them. However, in international law, this is not as simple as that. Countries fall within two broad categories, namely monist and dualist legal regimes (Aturu, 2006). For countries whose legal system is monism, ILO conventions which are international treaties are binding without the necessity of municipal legislation.

In dualist system and Nigeria is dualist, a treaty must first be domesticated and passed into law by the National parliament before, it can have the force of law. Thus, an ILO convention that has not been passed into law in Nigeria 
cannot be legally enforced. This position is backed by section 12 of the constitution of the federal Republic of Nigeria, 1999 which is the ground norm. The section provides unambiguously that no treaty between the federation and any other country shall have the force of law except to the extent to which any such treaty has been enacted into law by the National Assembly.

In spite of the fact that an undomesticated but ratified ILO convention cannot be legally enforced in Nigeria, the conventions are nevertheless useful as indicating best practice on a given labour or social issue. As a matter of fact the recent review of Nigerian labour laws was based on the need to bring the existing labour laws in line with ratified conventions which had not been passed into law by the National Assembly. Aturu (2006) however stressed the need for states to be familiar with the work of the ILO by virtue of its constitution and the necessity of the member states to constantly respect some fundamental principles on the constitution which specifically deals with labour matters.

\section{Conclusion}

The paper gave reasons why the ILO was established, a theoretical approach was adopted using the structural functionalist perspective as point of analysis. The paper identified ILO millennium objectives, structures, its core conventions and possible implications for labour laws in Nigeria. The ILO plays an important role in providing government with the necessary information and acts as a platform on which labour policies and laws are formulated. Such policies and laws in enable quick and rational decisions that better the lots of workers across the borders. The paper therefore concludes among others that member countries and relevant stakeholders should not relent in giving support to ILO to attain its great height of global achievements across national boundaries.

\section{References}

Aberle, D. F. and Cohen, A. R. (1959). The Functional Prerequisites of a Society Sutton, Ethics, Vol. Lx, No. 2

Adewumi, F. (1995c).The state and industrial relations in Nigeria: a study in labour control strategies. The Journal of politics. Lagos State University, Ojo, Lagos. Nigeria.Vol.2, No. 2, 1 \&2 pp 14-27.

Adewumi, F. (2002b).Trade unionism and industrial relations in Nigeria: issues and challenges for $21^{\text {st }}$ Century. In: African Journal of Labour Studies; Journal of the Department of Adult Education University of Ibadan, Nigeria, Vol.Nos.1 \& 2 9- 24.

Adewumi, F. (2010a).The state of workers' rights in Nigeria: an examination of the banking, oil and gas and telecommunications sectors. Lagos: Friedrich Ebert Stiftung, (Chapter 1).

Bankole, A. (2008).ILO to battle HIV/AIDS in place of work. Guardian Newspaper, Tuesday August $15^{\text {th }}$

David, S. \& Patricia M. (1993). The international labour organization and the welfare state; institutional effect on nations. International organization, Vol 47. pp 235-262. doi:10.1017/S0020818300027934, http://dx.doi.org/10.1017/S0020818300027934

Emery, F. F. (1980). Designing Socio - Technical Systems for Greenfield Sites. Journal of Occupational Behaviour” 1 (1) pp.19-27.

Esan, R.S.M. (1987). Legal framework of industrial relations in Nigeria in Otobo D \& Omole M. (eds.), Readings in industrial relations in Nigeria (2-19). Lagos: Malthouse Publishing Ltd.

Fajana S. (2006). Industrial relations in Nigeria: theory \& features. Lagos: Labofin Company (Chapter 4).

Kirkbride, S. (19870).The concept of power : a lacuna in industrial relations? The Australian Journal of the industrial Relations Society, 265-279.

Mamoria C. B; Mamoria, S. and Gankar, V. (2005). Dynamics of Industrial Relations $5^{\text {th }}$ edn., New Delhi: Himalaya Publishing House (Chapter 31).

Nigeria Labour Congress. Lagos \& International Labour Organisation.Geneva (1990). Report of Conference on Ratification and Implementation of ILO Conventions, Nigeria. Sept. 24-28.

Okougbo, E. (2004). Strategic Issues on the Dynamics of Industrial Relation: Theory and Practice. Lagos: Wepoapo Enterprises

Olorunfemi, F. (1997). 40 years of promoting industrial harmony \& enterprise competitiveness in Nigeria the history of NECA (19571997) (69-79) in Otobo D \& Omole M. (eds.), Ibadan: Malthouse Press Ltd. 
Onasanya (2005). Effective personnel management \& industrial relations. Lagos: Centre for Management Development. (Chapter 22).

Otite, O. (1994). Sociology: theory and applied. Lagos: Malthouse Press Ltd.( Chapter14).

Otobo, D. (1988). State and industrial relations in Nigeria. Lagos and London: Malthouse press Publishing Limited. (Chapter 5).

Parson, T. (1951) 'The Social System' Free Press of Glenwe, Pp. 126 - 127. (Chapter 4)

Shoremi, M.O. Edewor, P. A., and Olanrewaju A. O. (1999). The Science of Society: A Sociological Introduction, Ogun State, (CESA). (Chapter3).

The 1999 Constitution of the Federal Republic of Nigeria. Lagos: Federal Government press.

Table 1. International Labour Organisation Conventions Examined

\begin{tabular}{|c|c|c|c|}
\hline $\begin{array}{c}\text { Convention } \\
\text { number }\end{array}$ & Convention name & $\begin{array}{c}\text { Year } \\
\text { adopted }\end{array}$ & Reason for Adoption \\
\hline No. 1 & $\begin{array}{c}\text { Historic } 8 \text { hrs day and the } 48 \mathrm{hr} \\
\text { convention }\end{array}$ & 1919 & $\begin{array}{l}\text { Unified period of work hours per day } \\
\text { and in a week }\end{array}$ \\
\hline $\begin{array}{l}\text { Convention } \\
\text { No. } 87\end{array}$ & $\begin{array}{l}\text { Freedom of association and } \\
\text { protection, of right to organize } \\
\text { convention }\end{array}$ & 1948 & $\begin{array}{c}\text { Employers and workers gained freedom } \\
\text { to draw their constitution elect } \\
\text { representatives etc }\end{array}$ \\
\hline $\begin{array}{l}\text { Convention } \\
\text { No. } 98\end{array}$ & $\begin{array}{l}\text { The right to organize and collect } \\
\text { bargaining conventions }\end{array}$ & 1949 & $\begin{array}{c}\text { Workers freedom and right to enter into } \\
\text { collective bargaining with their } \\
\text { employers }\end{array}$ \\
\hline $\begin{array}{l}\text { Convention } \\
\text { No. } 29 \\
\end{array}$ & Forced Labc & 1930 & $\begin{array}{l}\text { Prohibits in turn an treatment inform of } \\
\text { employment and economic exploitation }\end{array}$ \\
\hline $\begin{array}{l}\text { Convention } \\
\text { No. } 100\end{array}$ & $\begin{array}{l}\text { Equal pay for work of equal value } \\
\text { for men \& women convention }\end{array}$ & 1951 & $\begin{array}{l}\text { Equal remuneration for men and } \\
\text { women for work of equal value. }\end{array}$ \\
\hline $\begin{array}{l}\text { Convention } \\
\text { No. } 111\end{array}$ & $\begin{array}{l}\text { Discrimination in respect of } \\
\text { employment and occupation } \\
\text { convention }\end{array}$ & 1958 & $\begin{array}{c}\text { Prevention against any form of } \\
\text { discrimination in terms of age, sex, } \\
\text { origin }\end{array}$ \\
\hline $\begin{array}{l}\text { Convention } \\
\text { No. } 155\end{array}$ & $\begin{array}{l}\text { Occupation safety and health } \\
\text { convention. }\end{array}$ & 1981 & $\begin{array}{c}\text { On ways choice of entions and } \\
\text { decisions and taken. }\end{array}$ \\
\hline
\end{tabular}

Source: Developed by Authors, 2011.

Table 2. Director -Generals of International Labour Organisation (ILO)

\begin{tabular}{|c|c|c|c|c|}
\hline S/n & Director General & Country of Origin & Tenure & $\begin{array}{c}\text { No. of } \\
\text { Years }\end{array}$ \\
\hline 1. & Albert Thomas & France & $1919-1932$ & 13 \\
\hline 2. & Harold Butler & United Kingdom & $1932-1938$ & 6 \\
\hline 3. & John Winant & United States & $1939-1941$ & 2 \\
\hline 4. & Edward Phelan & Ireland & $1941-1948$ & 7 \\
\hline 5. & David Mosel & United States & $1948-1970$ & 22 \\
\hline 6. & Welfred Jenks & United States & $1970-1973$ & 3 \\
\hline 7. & Francis Blanchard & France & $1973-1989$ & 16 \\
\hline 8. & Michael Hansenne & Belgium & $1989-1999$ & 10 \\
\hline & Juan Somavia & Chile & 1999 to date & 11 so far \\
\hline
\end{tabular}

Source: Developed by authors, 2011. 


\section{ILO}

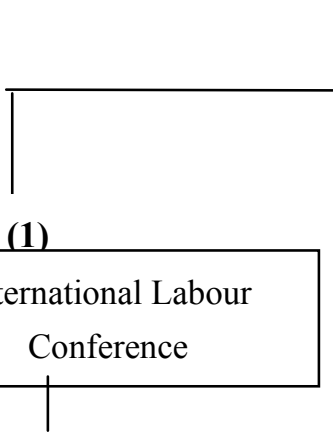

1. Examines Social Problems \&
2. Adopts conventions for ratification by Governments
3. It is the electoral college of the conference that elects the governing body

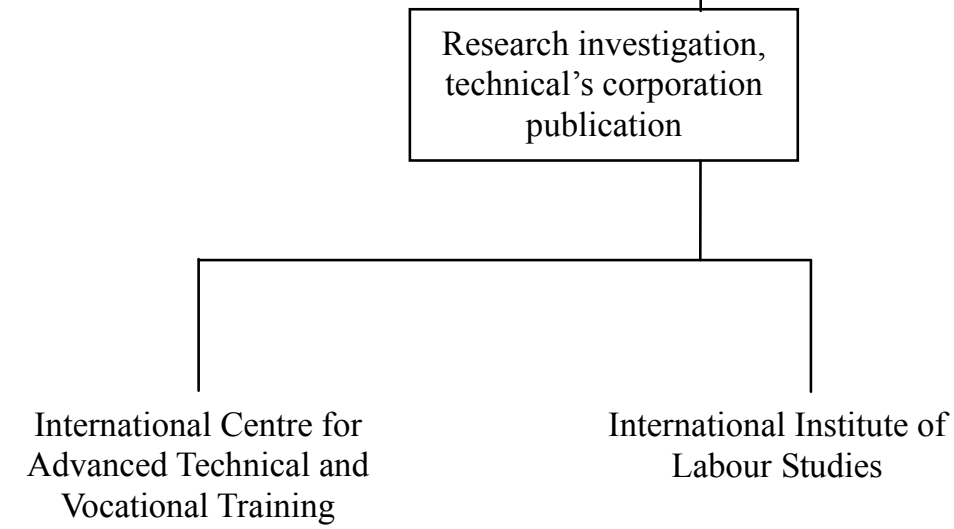

Figure 1. Organisational Structure of ILO

Source: Adapted from Mamoria, C. B., Mamoria, S. and Gankar, V. (2005). Dynamics of Industrial Relations (5th edn.) New Delhi: Himalaya Publishing House, P. 757 (Chapter 31) 